\title{
Study on Business English Translation under Multimedia Technology Environment
}

\author{
Wenjun Lu \\ School of Foreign Languages and Cultures, Beijing Wuzi University, Beijing 101149, China \\ luwenjun6210@sohu.com
}

\begin{abstract}
The paper reviews the main problems existed in the process of business English teaching in our country. First, Many students cannot understand the original materials concisely during the process of business English translation, and they don't attach much importance to cultural differences. Second, a lack of professional knowledge also exists in business English translation. Third, many students don't proofread after translation. The paper gives some suggestions on how to improve business English translation under multimedia technology environment.

Index Terms - Business English, Translation, Multimedia Technology Environment
\end{abstract}

\section{Introduction}

According to the syllabus published by National Education Commission in 2000, business English belongs to relevant professional courses and it is a necessary part for English language teaching, especially for English majors specializing in business English. It is commonly recognized that business English translation is a criterion to test business English majors' overall language capabilities. In recent years, as a branch of English for specific purposes, business English has become more and more important in business English teaching. An increasing number of language instructors and researchers are attaching more and more importance to business English teaching simultaneously. They actively involve in the discussion of the principles of business English translation teaching and understanding. Meanwhile, they put forward their understanding and the principles on business English translation. Some scholars point out that business English translation should abide by the principles such as faithfulness, exactness, consistency, cultural equivalence, functional equivalence, understanding of relevant professional knowledge, features of business English, the characteristics of business English [1,2]. Some other researchers also emphasizes that translators should understand the relevant knowledge and features concerning business English translation so that they can accomplish a satisfactory work while doing business English translation. In addition, translators should adhere to the principle of consistency in the process of business English translation.[3]

There is no doubt that the above-mentioned discussions on the principles of business English translation have shed some light on the teaching of business English translation. However, with the increasing number of college English students, the training of business English translation personnel cannot satisfy the market demand for business English translation personnel. Many imperfections still exist in the process of business English translation and there is still much room for the improvement of business English translation instruction. For example, some students will start to translate the source language without fully understanding the implied meaning of the source language, to say nothing of translating the original version into idiomatic target languages. In the following part, the paper will have a brief discussion on the imperfections in the process of business English translation teaching and put forward some significant suggestion on how to tackle the problems existed in business English translation.

\section{Problems in the Teaching of Business English Translation}

It is commonly acknowledged that the correct understanding plays a vital role in the process of business English translation. Otherwise, the translated version may not be able to express the original version exactly. Next, it is also important to think over the cultural differenced in the process of business English translation, for language is the carrier of culture which also plays a very important role in business English translation. Translation is not only the conversion of the source and target languages, but also the exchange and transfer of the two cultures. In the process of business English translation, expertise is the premise of faithful expression and the translation quality of the original. Similarly, proofreading the translation is an indispensable part of business English translation. However, based on the analysis of the teaching of business English translation and students' translation exercises, it is found that the abovementioned problems are commonly existed in the process of the teaching of business English translation. Sometime, even the business English instructors don't pay enough attention to the above-mentions problems, let alone encourage students to pay particular attention to these problems while doing the translation work.

Business English translation process involves a wide range of content understanding of the primitive and the requirements are very high, so the translation process needs to be more careful and the thinking needs to be more profound. For example, the following excerpt is from the text of a unit of investment business: Airport Economic Development Zone, the Tianzhu Export Processing Zone, the modern automobile production base in Beijing Airport Logistics Park, the new International Exhibition center, country business district together constitutes the capital airport economic zone. This is the correct translation of 
Beijing Airport Logistics Park. However, many students cannot correctly translation the original and it is inevitable that they make some mistakes in the process of translation. The reason is that they cannot fully understand the original version of the materials.

A lack of thinking over the cultural differences and background knowledge is another problem existed in the process of business English translation. Different cultural systems are firmly existed in people's way of thinking. Therefore, it is necessary to think over the cultural differences in the process of business English translation in order to achieve the goal of cultural and functional equivalence. To achieve cultural and functional equivalence means to make sure that the translated version and the original version are equivalent in terms of the content of information, the way of expression, the stylistic expression, the languages and cultural factors and many other issues[4]. "Asian Tigers" refers to Hong Kong and Taiwan of China, the South Korea and Singapore in the 1980s. They are very successful in terms of economic development. The translated version should be "the four Asian Tigers" instead of "the four Asian Dragons" because of cultural differences. However of the 102 students, 95 students translated the phrases as "the four Asian Dragon" because they lack the cultural differences between the two cultural systems. It is clear the cultural knowledge plays a very important role in the process of business English translation and teaching. There is no doubt that both teachers and students should attach much importance to cultural differences in business English translation and teaching.

As we all know, the "dragon" in the Eastern and Western cultures are completely different. The Chinese nation has been regarded as "Descendants of the Dragon, the dragon in the hearts of Chinese people is a symbol of wisdom and strength, the dragon is the fetish, the supreme majesty. In contrast, in Western culture, the dragon is a domineering and aggressive monster. Obviously, without considering the differences in cultural factors, it is difficult to accurately translate the original version to the target language, especially in business English translation. It is pointed out that exploring Western culture will help one to find that Westerners think dragon is a more powerful animal, some kind of terrible animal. The translation of "Asian Tigers" for "the Four Asian Tigers" has basically reached the cultural equivalence in terms of information and culture equivalence [5].

It is very necessary to understand the relevant professional knowledge in the process of business English translation, for it is essential to avoid making mistakes in business English translation. It is a must to understand the specific usage of business English vocabulary if one wants to avoid making errors in translation. Furthermore, many students don't proofread their translation after they finish translating the original materials. Many students don't use dictionaries in the process of business English translation, and they neglect the fact the some business English vocabulary has its own specific meaning. It is hard for them to understand the original material concisely, not to mention finish a satisfactory translation work.

With the rapid development of multimedia and computer sciences, the multimedia and computer play a more and more important role in the process of business English translation. Computers can help translators a lot in translation. For example, some translators simple use the internet in the process of translation. They use computer technology to translate the source language into the target language. In this way, it can save translators much energy and time. However, the quality of the target language is not so satisfactory as they hope. The reason is that computers cannot work as human beings do. Computers can neither recognize the implied meaning of the source language nor work out the source language into the idiomatic target language. This is one of the problems existed in the process of business English translation. In fact, both instructors and students must realize the fact that computers cannot completely replace human beings in the process of translation, especially in business English translation.

\section{Some Measures on How to Solve the problems}

Similar to other kinds of translation, to understand the original materials exactly is the foundation of faithfulness and accuracy in business English translation. Accurate understanding is the first step in business English translation. To achieve an accurate understanding and expression, it is required that translators must have a solid foundation of language skills. Therefore, in the teaching of business English translation, the cultivation of basic translation skills training is essential. Teachers must have a rigorous teaching style in teaching business English translation. They must cultivate their students the strict translation styles from the very beginning of practicing business English translation. In the process the teaching of business English translation, teachers should encourage students to look up dictionaries frequently and consult the reference books relevant to professional knowledge of business English translation. Teacher must let students realize the fact that it is not adequate to business English translation if one only acquires a large amount of vocabulary and grammatical knowledge. In addition to classroom teaching, teachers should encourage students to think actively in translating business English and cultivate a positive learning habit. Students should realize the fact that business English not only involves international economy, trade, finance and other aspects of business expertise, but also relates to the professional knowledge of international commercial law, international exchange, insurance, which determines that there is a enormous difference between the business English translation and other kinds of English translation. Therefore, in the process of business English translation, teachers should remind students that they must completely and deeply understand the original materials, and they cannot translation mechanical according to the dictionary, either. 
Students need to know that it is necessary to know the lexical features, translation methodologies and business knowledge organically, and must link the knowledge closely if they want to achieve a satisfactory translation work. Only in this way can they avoid making errors in business English translation [6]. Of course, teachers must have a solid foundation of language skills, and be familiar with the relevant expertise as far as possible, so as to accurately understand the meaning of the primitive materials. Teachers should do their utmost to achieve the ideal unity of the teaching of business English translation knowledge and professional knowledge and therefore achieve a best teaching result.

Translation is an important channel for mutual communication between different cultures. It is a direct factor in determining the effect of cultural transmission. Similarly, the teaching of business English translation should focus on the transmission of cultural information, and strive to achieve cultural equivalence. This requires that the Business English teachers not only have a solid knowledge of English language, but also familiar with the relevant foundation of business English expertise, but also be familiar with relevant professional knowledge. They should also pay attention to the teaching of cultural information, and thus to achieve cultural informational equivalence in accordance with the relevant standards of the International business English translation. It is important to avoid translation errors because of cultural differences in the process of business English translation. It requires that translators understand the characteristics of primitive culture in the process of translation. For example, it is necessary to let students know that colors, numbers represent different symbolic meanings in different cultures. A color which represents a positive meaning in one culture may represent a negative meaning in another culture. Similarly, a number which represents a positive meaning in one culture may represent a negative meaning in another culture. In order to avoid making errors in business English translation because of cultural differences, especially in translation of advertisements and brands of products, teachers must make students be aware of these cultural differences so that they may avoid making such errors in the process of business English translation. Some scholars once points out that it is necessary to cultivate students to understand the cultural differences between different cultures and let them know that English translation involves both language and cultures [7].

In the process of business English translation, it is required that translators not only understand the cultural differences between different nations, but also master the relevant professional knowledge of business English. Translators must be familiar with the relevant professional knowledge of business English and master the characteristics of business English vocabulary if they want to achieve a standard and unified translation principle of business English. This requires that business English translation teachers keep on learning the professional knowledge of business English. In recent years, the bilateral trade volume between China and other countries have increased a lot, so business English translation teachers should advance with the times, pay attention to the new vocabulary appearing in their own field, understand the lexical features of business English vocabulary. Only in this way can they achieve a satisfactory teaching effect in business English translation. Both inside and outside the classroom, they should let students realize their shortcomings and imperfections through doing a large number of business English translation exercises. This is one of the correct ways to train qualified business English translation personnel and meet the needs of market.

Proof reading is an essential part in business English translation if translators want to guarantee the quality of the translation. In addition to teachers' grading of students' translation work, students can grade their exercises between themselves. Self-revision is undoubtedly an indispensable step in business English translation. During the process of proofreading, translators should examine the following issues such as faithfulness, fluency. Furthermore, they should scrutinize whether there is a mistranslation and a leakage translation of the original material. They should also check if the translation really achieves functional equivalence. Students must realize that the frequent use of dictionaries and other reference books is the foundation of a correct translation. Business English translation teachers should try to ask the students to develop the habit of using dictionaries in the usual translation exercises process. Students must understand that some jargon of the business English translation must be understood by looking up dictionaries. They should try to avoid using electronic dictionaries if possible. At the same time, the understanding of some terminology should be understood by consulting the relevant professional staff. It is the only way to avoid making mistakes in business English translation so that the translated version is close to the standard version of business English translation.

It is not surprising that internet has provided human beings with much benefits and convenience. There is no doubt that human beings can also make the best of internet in the process of translation, and business English translation as well. It is well known that it is inevitable that translators will encounter some novel words in the process of translation. It will be very time-consuming if translators use the traditional paper dictionary to look up the new words. However, internet can help translators solve this problem. For instance, both google.com and baidu.com have the function to do the translation work. Of course, the quality of the translation is far from satisfaction if translators simple use their relevant software to translate. Although the translation work done by computers is not satisfactory, to some extent, it can make the translation work become easier. It can save the translators much time by not looking up the new words in the dictionary. That is, both 
google.com and baidu.com have the potential to translate the source language into the target language in terms of novel and technical words, which can save translators much time. It is one of the advantages of multimedia and computer facilities. Translators can make use of internet and computers in the multimedia era.

\section{Suggestions on Business English Translation Under Multimedia Technology Environment}

After China's entry into the WTO, the trade volumes with foreign countries are increasing dramatically. Consequently, the requirement for the teaching of foreign language, especially the teaching of business English translation, is put into a new high because a lot of business English translation is conducted by the Chinese translators themselves. The teaching of business English translation plays a vital role in training the qualified personnel of business English translators. The paper discusses some problems existed in the process of the teaching of business English translation and put forward some measures on how to tackle these problems. It goes without saying that there are still some other problems in the teaching of business English translation, apart from the issues discussed in the paper. It is essential for students to strengthen their fundamental Chinese and English language skills and cultural enrichment as well as their learning of the professional knowledge of business English. Both teachers and students should actively utilize the multimedia technology in the process of business English translation.

As cultures play a very important role in the process of translation, especially business English translation, instructors should inform students the importance of the function of culture in business English translation. It is necessary that translators get familiar with the culture of target language and bear the language features of business English translation principles, which requires business English instructors build up a solid foundation of business English language skills, business English professional knowledge and other relevant knowledge involved in business English translation. Only in this way can the instruction of business English translation be put into a new high. In addition, both business English teachers and students should be able to keep pace with the times, that is, they should keep on learning the new terminology emerging in the business English translation field and pay attention to the latest development in their own fields. Besides, both business English teachers and students should be able to strive to master the features of business English in order to be able to recognize their own imperfections in the process of business English translation.
Finally, both instructors and students should cultivate the habit of checking up their translation work after they accomplish the translation. The check up work can carry out between students, or instructors can help students to improve their proofreading. For example, instructors can inform their students on what measures should be taken while proofreading. Students must understand that proofreading is a must in the process of business English translation. It is required that they check up their translation after they finish it because only in this way can they ensure to work out a high quality of translation. Translators should scrutinize the following issues in business English translation, that is, the faithfulness, smoothness and elegance of their translation. In addition, translators should check up whether there is leakage mistranslation, or their translation has achieved functional equivalence. Translators should be aware of the fact that dictionaries, reference books and professional reference books are only the basis of correct translation. These issues cannot guarantee that they can work out a perfect business English translation work. It is essential that students be aware of the fact that some business English terminologies bear special meanings in the context. Translators must attach much importance to the exact meaning of these terminologies do their best to find out the appropriate meaning in the context.

\section{Conclusion}

The issue of business English translation is of great importance to business English instructors and students. Instructors should be able to recognize the problems and difficulties existed in business English translation. They will be able to achieve a better teaching result if they can take the above-mentioned measures to solve the problems and difficulties in their instruction. With the help of multimedia facilities in the process of teaching, it is believed that the instruction of business English translation can be dramatically improved.

\section{References}

[1] Liu F G. the Principle Exploration of Business and Commercial English Translation Chinese Translation. 2002.PP 45-49

[2] Zhang J Y. Understanding in Teaching of Business English and Translation. Xi'an International Studies University2003. pp 28 -30

[3] Duan M M. Translation Strategy of Modern Business English Chinese Science Translation. 2005.pp 34-36

[4] Nida, E. A. Language and Culture: Context in Translating (Shanghai: Foreign Language Education Press) 2001

[5] Ma Y W. Business Culture and the Translation of English-speaking Backgrounds Social Sciences Review2007. pp 320-322

[6] Liu B Y. The Lexical Features and Its Translation of Business English Beijing Second International Studies University 2007.pp34-37

[7] Lee T Z. Problems and Countermeasures in Business English Translation Shanghai Translation 2005.pp23 -25. 